


\title{
INCLUSION OF KAPOK SEED OIL IN THE DIET FOR GROWING OF THIN-TAILED SHEEP TO REDUCE CHOLESTEROL AND TO IMPROVE OMEGA-SIX FATTY ACID CONTENTS OF LAMB
}

\author{
Widiyanto $^{1}$, M. Soejono ${ }^{2}$, H. Hartadi ${ }^{2}$, Z. Bachrudin ${ }^{2}$ and Surahmanto ${ }^{2}$ \\ ${ }^{1}$ Faculty of Animal Agriculture Diponegoro University \\ Tembalang Campus, Semarang 50275 - Indonesia \\ ${ }^{2}$ Faculty of Animal Science Gadjah Mada University \\ Jl. Agro, Karangmalang, Yogyakarta - Indonesia \\ Corresponding E-mail: widiyantowidiyanto75@yahoo.com
}

Received July 19, 2012; Accepted August 24, 2012

\begin{abstract}
ABSTRAK
Penelitian ini dilakukan untuk mengkaji pengaruh suplementasi minyak biji kapok (MBK) terproteksi dalam kombinasinya dengan konsentrat, dalam hal ini bekatul terhadap status lipida daging domba ekor tipis (DET) yang mendapat rumput lapangan (RL) sebagai pakan basal. Sebanyak 24 ekor domba DET jantan digunakan sebagai bahan percobaan yang dibagi dalam 8 kelompok perlakuan. Terdapat 2 faktor perlakuan, yakni suplementasi MBK (faktor I) dan suplementasi konsentrat yakni bekatul (faktor II). Faktor I terdiri atas 2 aras, yakni $0 \%$ (S0) dan 10\% (S1), sedangkan faktor II terdiri atas 4 aras, yakni $0 \%(\mathrm{~K} 0) ; 15 \%(\mathrm{~K} 1) ; 30 \%(\mathrm{~K} 2)$ dan $45 \%(\mathrm{~K} 3)$, berdasarkan konsumsi BK. Variabel yang diukur meliputi kandungan lemak intramuskuler (LIM), bilangan iodin (BI) asam lemak daging, kandungan kolesterol dan asam lemak omega 6 daging (dalam hal ini asam linoleat). Data yang terkumpul diolah secara statistik dengan analisis ragam, pola perlakuan faktorial $2 \times 4$ dalam rancangan acak lengkap (RAL). Kandungan LIM domba-domba yang mendapat suplemen MBK pada aras 0 dan dedak halus $15 \%$ tidak berbeda nyata dengan kandungan LIM domba-domba tanpa suplementasi MBK dengan aras pemberian bekatul yang sama (3,45 dan 3,99 vs 3,01 dan 3,75\%). Suplementasi MBK terproteksi dalam kombinasinya dengan 30 dan $45 \%$ dedak halus menghasilkan peningkatan nyata ( $\mathrm{P}<0,05)$ kandungan LIM (4,75 dan $5,93 \%$ vs 4,32 dan $5,40 \%)$ dan penurunan nyata $(\mathrm{P}<0,05)$ kandungan kolesterol daging (62,46 dan $65,26 \mathrm{mg} / 100 \mathrm{~g}$ vs 89,21 dan 72,63 mg/100 g) juga peningkatan nyata $(\mathrm{P}<0,05)$ proporsi asam linoleat $(15,52$ dan $18,25 \% 1$ vs 3,68 dan $4,045 \%)$ serta BI (12,52 dan 10,25 vs 4,09 dan 4,98).
\end{abstract}

Kata Kunci : Minyak Biji Kapok, Proteksi Asam Linoleat, Kolesterol, Daging, Domba Ekor Tipis

\begin{abstract}
This research was conducted to study the influence of protected kapok seed oil (PKSO) supplementation in its combination with concentrate, in this case was rice bran (RB) on lipid content of thin tailed sheep received field grass as basal feed. A number of 24 heads of male thin-tailed sheep were used as experimental material. These sheep were divided into 8 treatment groups. There were two treatment factors, i.e. : PKSO supplementation (S) as factor I and RB supplementation (K) as factor II. Factor I consisted of 2 levels, i.e. 0\% (S0) and 10\% (S1), whereas factor II consist of 4 levels, i.e. 0\% (K0), $15 \%(\mathrm{~K} 1), 30 \%(\mathrm{~K} 2)$ and $45 \%$ (K3), respectively, based on dry matter (DM) intake. Several variables were measured, namely content of intra muscular fat (IMF), iodine number of muscular fatty acid, content of meat cholesterol and omega 6 fatty acid (in this case linoleic acid). The collected data were statistically analyzed by analysis of variance with factorial treatment pattern $(2 \times 4)$ in completely randomized design (CRD). Content of IMF in sheep supplemented with 0 and $15 \%$ KSO levels was not significantly different from those without kapok seed oil (KSO) supplementation at the same level of RB feeding (3.45 and 3.99\% vs 3.01 and 3.75\%). Supplementation of protected KSO in combination with 30 and $45 \%$ RP resulted in significantly increased $(\mathrm{P}<0.05)$ IMF content $(4.75$ and $5.93 \%$ vs 4.32 and $5.40 \%)$ and significantly decreased $(\mathrm{P}<0.05)$ meat chollesterol content $(62.46$ and $65.26 \mathrm{mg} / 100 \mathrm{~g}$
\end{abstract}


vs 89.21 and $72.63 \mathrm{mg} / 100 \mathrm{~g})$ also significantly increased $(\mathrm{P}<0.05)$ linoleic acid proportion $(15.52$ and $18.25 \%$ vs 3.68 and $4.04 \%$ ) and iodine number (12.52 and 10.25 vs 4.09 and 4.98).

Keywords : Kapok Seed Oil, Protection, Cholesterol, Linoleic Acid, Meat, Java Thin Tailed Sheep

\section{INTRODUCTION}

Beef consumption in Indonesia was about $23 \%$, whereas small ruminant meat (sheep and goat) was only 5\% (Ditjen Bina Produksi Peternakan, 2006). According to Arinto (2006) the low consumption of lab and mutton, due to public cholesterol phobia issue. The effort to solve those problems are needed to be conducted to increase the demand of lamb and mutton in Indonesia. Animal production technology which could decrease the cholesterol content and fatty acid saturation degree and/or increase the essential fatty acid content (in this case omega 6 fatty acid, namely linoleic acid) in lamb, was expected to solve those problems (Sheridan et al., 2003; Wood et al., 2004; Nuernberg et al., 2006; Chen et al., 2010).

One of the alternative technology, was polyunsaturated fatty acids (PUFA) source supplementation, in this case was omega 6 fatty acids, namely : linoleic acid. There was a close relation between the increasing of PUFA intake and meat quality (Doureau et al., 2010). Preferentialy PUFA will be deposited in the muscle (Christie, 1979b; Raes et al., 2004). Those also affect the composition and saturation degree of meat fatty acid that contributed to consumer health. The saturation degree of meat fatty acid decreased along with the high PUFA content (Laliotis et al., 2010). In addition to metabolic function that had been described above, PUFA (in this case omega 6 fatty acids) especially linoleic acid and arachidonic acid had a role in maintenance of epidermal water barrier in related to skin health (Murray et al., 1997). Arachidonic acid was also the eicosanoid precursor which is very important in immunity maintenance (Sardesai, 1992). Decreasing of meat fatty acid saturation degree was important in related to the role of PUFA in control the cholesterol status. Borys et al. (2004) stated the interrelationship between the increasing of cholesterol concentration and unsaturated fatty acid consumption, also the role of PUFA in decreasing of blood cholesterol concentration. Linoleic acid was phosphatidilcholline component, which was the main phospholipid in high density lipoprotein (HDL). Those could carry out the cholesterol from periphery tissue as well as other lipoprotein for its oxydation in the liver (Dodson et al., 2010). To obtain the real benefit of PUFA in ruminant feeding, supplementation of PUFA source was required in adequate level and in protected form. Protection treatment was required to avoid the PUFA from biohydrogenation by rumen microbes (Scollan et al., 2003; Chilliard et al., 2007). Protection was also required to eliminate the negative impact of the high level PUFA supplementation, namely the decreasing of fiber degradability (Aharoni et al., 2004). Partial protection of PUFA source, enable to utilize effectively the influence of PUFA to increase the ruminal energy efficiency and propionic acid production or decreased the acetic acid / propionic acid molar proportion ratio (Jale et al., 2007).

Kapok seed oil (KSO) was one of potential PUFA source. According to Widiyanto (2010), PUFA proportion in KSO was $71.98 \%$. About $62.32 \%$ of those was linoleic acid, whereas oleic and linolenic acid were 33.35 and $4.32 \%$, respectively.

The aims of this investigation were to study the influence of protected KSO supplementation on lipid status of lamb, especially in cholesterol and omega-six fatty acid. This investigation also resulted the technology of omega-six fatty acid source protection and its supplementation on small ruminant to produce the healthy lamb as high quality food.

\section{MATERIALS AND METHODS}

The materials in this investigation were protected KSO as feeding supplement, field grass (FG) as basal feed, rice bran (RB), 24 heads of java thin-tailed sheep at 6 month ages with 12.87 $\pm 1.53 \mathrm{~kg}$ average body weight, as experimental unit. The PUFA source (KSO) was used at $10 \%$ supplementation level with $75 \%$ protection level (Widiyanto et al., 2007). The major equipments consisted of animal balance, feed balance, analytical balance, individual pen and its equipment, feces bag, venoject tubes and its needle, waterbatch, ultracentrifuge and gas chromatography. The accuracy of animal balance was $1 \mathrm{~g}$, feed balance was $1 \mathrm{~g}$, and analytical balance was $0.0001 \mathrm{mg}$. Venoject tubes and its 
Table 1. Nutrient Composition of Experimental Feed (Dry Matter Basis)

\begin{tabular}{lccccc}
\hline \multicolumn{1}{c}{ Feedstuff } & CP $(\%)$ & CF $(\%)$ & Lipid (\%) & Ash (\%) & NFE (\%) \\
\hline Field Grass & 10.16 & 32.66 & 1.37 & 16.58 & 39.23 \\
Rice Bran & 14.04 & 15.81 & 17.08 & 10.08 & 42.99 \\
\hline
\end{tabular}

Source: Widiyanto et al. (2007)

CP: Crude Protein; CF: Crude Fiber; NFE: Nitrogen Free Extract

needle were used for blood sampling, water bath as heater for KSO saponification process. The ultracentrifuge was used to determine lipoprotein, whereas gas chromatography was used to determine PUFA proportion.

Twenty four heads of experimental sheep were divided into 8 groups based on treatment combination. There were 2 treatment factors, those were protected KSO supplementation (S) as factor 1 and feeding RB (K) as factor 2. Treatment of factor 1 consisted of 2 levels, namely without supplementation ( $\mathrm{S} 0)$ and with supplementation (S1). Treatment of factor 2 consisted of 4 levels, namely: $0 \%(\mathrm{~K} 0) ; 15 \%(\mathrm{~K} 1), 30 \%(\mathrm{~K} 2)$ and $45 \%$ (K3).

The experiment proceeded for 3 months, including 10 days adaptation period, 10 days preliminary period and 70 days observation period. During experimental period, forage was fed ad libitum. Concentrate was fed every morning, whereas water was supplied continously. Mineral mixture consisted of limestone, bone meal and salt (1:1:1) to be fed free choicely (Tillman, 1978).

Feed consumption and body weight data were collected after preliminary period. Weighing of body weight were conducted weekly, in the morning before feeding, as the base of supplementation and was used for calculation of supplementation feeding. The feed efficiency was expressed as body weight gain per unit feed consumed. Determination of dry matter, organic matter and lipid digestibilities were conducted in the second month of feeding experiment, by total collection method (Moore, cited by Harris, 1970). At the end of feeding experiment, all of experimental sheep were slaughtered, which done after 12 hours fasting to determine the slaughtered weight. Carcass were weighed, then the meat was separated from the bone to calculate meat/bone ratio. Meat samples from $m$. longiisimus thoracis were used to determine intramuscular fat (IMF), meat cholesterol content (Lieberman-Burchard, cited by Tranggono et al., 1979) and iodine number (Plumer, 1971). Determination of relative proportion of meat linoleic acid was done according to Ponnampalam et al. (2001)

The collected data were analyzed statistically by analysis of variance in completely randomized design. Difference of means between treatment groups were analyzed by Duncan method (Sugandi and Sugiarto, 1993).

\section{RESULTS AND DISCUSSION}

Study in meat lipid content was based on level of intramuscular fat (IMF) and cholesterol, relative proportion of linoleic acid and iodine number (IN).

\section{Intramuscular Fat}

Intramuscular fat (IMF) consists of structural and deposit fat. Most of structural fat found as biomembrane integral constituent, especially as phospholipid, whereas deposit lipid found in interfascilular adipose tissue, most as triglycerides (TG) and smaller part as mono and diglycerides, cholesterol, cholesterylester (CE), non esterified fatty acids (NEFA), and phospholipids (Dodson $e t$ al., 2010).

Intramuscular fat also found in cellular droplet (Christie, 1979a). Variance analysis showed the influence of protected KSO supplementation and feeding RB, and its interaction on IMF content in experimental sheep $(\mathrm{P}<0.05)$.

Intramuscular fat content in $\mathrm{m}$. longisimus thoracis of sheep received $\mathrm{RB}$ at $0,15,30$ and $45 \%$ levels without KSO supplementation were $3.04,3.875,4.32$ and $5.40 \%$, respectively, whereas in groups receiving protected KSO were 3.45, 3.51, 4.75 and 5.93, respectively (Tabel 4.). Feeding RB to unsupplemented sheep groups increased the IMF content $(\mathrm{P}<0.05)$. The increasing of those IMF content could occur among others because the increasing of 
consumption either lipid or readily available carbohydrate (RAC) intake. According to Bell (1979) and Pethick et al. (2005), the RAC had important role in lipogenesis, namely as NADPH source through the pentose phosphate pathway and glycerol-3phosphate source for long chain fatty acid esterification by activation of glicolysis and glycerol phosphate dehydrogenase. Bonnet et al. (2007) stated that decreasing of molar proportion ratio of acetic acid/ propionic acid (A/P) due to increasing of RAC consumption will increase glucose production. Increasing of glucose production stimulated insulin hormone secretion that had important role in lipogenesis. Zhang et al. (2009) indicated that supplementation of $180 \mathrm{~g}$ starch per day to sheep resulted in higher $(\mathrm{P}<0.05)$ blood insulin hormone concentration than sheep received $120 \mathrm{~g}$ starch per day (0.64 vs 0.53 ng/ml). Faulconnier et al. (2007) and Vakili et al. (2011) stated that insulin increased lipogenesis by lipolysis inhibition and increased the glucose entry into adipocyte for lipogenesis. The influence of those RAC on IMF was higher along with increasing of $\mathrm{RB}$ feeding (up to 45\%). Lipid consumption in sheep without feeding $\mathrm{RB}$ with protected KSO supplementation $(\mathrm{S} 1 \mathrm{~K} 0)$ were higher than S0K0 group, that was 48.54 vs $6.04 \mathrm{~g}$ (Table 2), but there were not significant difference of IMF content between those groups. It could occur because PUFA from protected KSO inhibited the longchain fatty acid synthesis in adipose tissue (Bergen et al., 2005). According to Clarke (1993), French et al. (2000) and Hess et al. (2008), PUFA inhibited the transcription of fatty acid synthetase enzyme, so that the de novo fatty acid synthesis was inhibited, thus the IMF content was significantly different, allthough lipid consumption in $\mathrm{S} 1 \mathrm{~K} 0$ was higher than SOK0 group. The influence of those fatty acid synthesis was dominant than $15 \%$ level RB supplementation, so that IMF content between S1K1 and S1K0 sheep group were not different and tends to lower than SOK1. The influence of feeding $\mathrm{RB}$ on lipogenesis was more dominant than inhibition of de novo fatty acid synthesis occured in 30 and $40 \%$ level of feeding RB, so that IMF content in S1K2 group was higher $(\mathrm{P}<0.05)$ than those in S0K2 $(4.75 \%$ vs $4.32 \%)$ and IMF content in $\mathrm{S} 1 \mathrm{~K} 3$ was higher $(\mathrm{P}<0.05)$ than S0K3 group (5.93\% vs 5.40\%). Deposition of PUFA from KSO became more effective by the increasing of glycerol phosphate supply and the decreasing of PUFA oxydation due to increasing of glucose supply, along with the increasing of RB feeding level (Bell, 1979; Christie, 1979b). Protected KSO supplementation combined with $30 \%$ and $45 \%$ RB feeding level allowed the higher supply of PUFA than the other treatment groups. The higher supply of PUFA allowed its deposition in $\mathrm{TG}$ form, in addition to

Table 2. Dry Matter Intake of Field Grass, Rice Bran, Crude Protein, Lipid and Total Digestible Nutrient

\begin{tabular}{lrrrrrr}
\hline $\begin{array}{c}\text { Treatment } \\
\text { Replication }\end{array}$ & FG & RB & DM (Total) & CP & Lipid*) & TDN \\
\hline S0K0 & 391 & - & 391 & 47 & 6.04 & 201 \\
S0K1 & 378 & 62 & 437 & 53 & 16.66 & 250.58 \\
S0K2 & 389 & 150 & 539 & 68 & 31.76 & 336.32 \\
S0K3 & 313 & 235 & 548 & 71 & 45.21 & 369.06 \\
S1K0 & 413 & - & 413 & 50 & 48.54 & 285.53 \\
S1K1 & 466 & 80 & 546 & 64 & 73.71 & 414.44 \\
S1K2 & 451 & 161 & 612 & 74 & 87.95 & 482.80 \\
S1K3 & 318 & 239 & 559 & 71 & 98.87 & 463.64 \\
\hline
\end{tabular}

Source : Widiyanto et al. (2009)

*) Lipid consumption included the lipid from KSO supplementation

FG: Field Grass; RB: Rice Brand; DM: Dry Matter; CP: Crude Protein; TDN: Total Digestible Nutrient 
phospholipid and CE form. Those lipid will be hydrolized quickly by lipoprotein lipase and then deposited in adipose tissue, so that increased the IMF content (Christie, 1979b).

\section{Meat Cholesterol}

Intestinum was main cholesterogenesis place in ruminant animal. Those cholesterogenesis increased along with the increasing of lipid consumption. This increasing was required to facilitate the abssorbed lipid transport (Bell, 1979). As for cholesterol synthesis level in adipose tissue was not influenced by fat supplementation (Vernon, 1979). Table 4 indicated that lamb cholesterol level in SOK0 treatment group was lower $(\mathrm{P}<0.05)$ than those in S0K1 and S0K2 $(74.15 \mathrm{mg} / 100 \mathrm{~g}$ vs 86.11 and $89.21 \mathrm{mg} / 100 \mathrm{~g}$ ). It could occur due to lower lipid consumption by S0K0 sheeps group (6.04 g vs 16.66 and $31.76 \mathrm{~g}$ ), so that intestinal cholesterol synthesis rate in SOK0 sheep group also lower than those in S0K1 and SOK2. The low of cholesterol synthesis rate did not allow the increasing of cholesterol deposition in intramuscular adipose tissue. Meat cholesterol concentration in sheep received $45 \%$ level of RB without KSO supplementation $(72.63 \mathrm{mg} / 100 \mathrm{~g})$ was not significantly different from those in sheep without KSO supplementation and RB feeding $(74.95 \mathrm{mg} / 100 \mathrm{~g})$ and it was lower $(\mathrm{P}<0.5)$ than S0K1 $(86.11 \mathrm{mg} / 100 \mathrm{~g})$ or in S0K2 $(89.21$ $\mathrm{mg} / 100 \mathrm{~g})$.

The high lipid consumption in S0K3 group $(45.21 \mathrm{~g})$ as could be seen in Table 2$)$ required the increasing of bile acid secretion for its digestion and absorption. The higher daily body weight gain

Table 3. Daily Body Weight Gain, Blood Plasm Triglyceride, and Cholesterol Levels of Sheep

\begin{tabular}{|c|c|c|c|c|c|c|}
\hline Suplementation & Concentrate & $\begin{array}{c}\text { DBWG } \\
(\mathrm{g})\end{array}$ & $\begin{array}{c}\mathrm{TG} \\
(\mathrm{mM})\end{array}$ & $\begin{array}{l}\text { Total chol } \\
\quad(\mathrm{mM})\end{array}$ & $\begin{array}{l}\text { LDL chol } \\
\quad(\mathrm{mM})\end{array}$ & $\begin{array}{l}\text { HDL chol } \\
\quad(\mathrm{mM})\end{array}$ \\
\hline \multirow[t]{4}{*}{ So } & K0 & $54^{\mathrm{c}}$ & $0.11^{\mathrm{d}}$ & $1.35^{\mathrm{d}}$ & $0.57^{\mathrm{e}}$ & $0.67^{\mathrm{f}}$ \\
\hline & K1 & $62^{\mathrm{d}}$ & $0.15^{\mathrm{c}}$ & $1.54^{\mathrm{c}}$ & $0.66^{\mathrm{d}}$ & $0.75^{\mathrm{e}}$ \\
\hline & $\mathrm{K} 2$ & $82^{\mathrm{c}}$ & $0.27^{\mathrm{b}}$ & $1.75^{\mathrm{b}}$ & $0.75^{\mathrm{bc}}$ & $0.81^{\mathrm{d}}$ \\
\hline & K3 & $89^{\mathrm{b}}$ & $0.30^{\mathrm{ab}}$ & $1.93^{\mathrm{a}}$ & $0.85^{\mathrm{a}}$ & $0.92^{\mathrm{c}}$ \\
\hline \multirow[t]{4}{*}{$\mathrm{S} 1$} & K0 & $60^{\mathrm{d}}$ & $0.17^{\mathrm{c}}$ & $1.98^{\mathrm{a}}$ & $0.70^{\mathrm{cd}}$ & $0.98^{\mathrm{c}}$ \\
\hline & $\mathrm{K} 1$ & $83^{\mathrm{c}}$ & $0.28^{b}$ & $1.93^{\mathrm{a}}$ & $0.79^{\mathrm{ab}}$ & $0.97^{\mathrm{c}}$ \\
\hline & $\mathrm{K} 2$ & $99^{\mathrm{a}}$ & $0.33^{\mathrm{a}}$ & $1.96^{\mathrm{a}}$ & $0.73^{\mathrm{bcd}}$ & $1.14^{\mathrm{b}}$ \\
\hline & $\mathrm{K} 3$ & $95^{\mathrm{a}}$ & $0.31^{\mathrm{ab}}$ & $1.99^{\mathrm{a}}$ & $0.69^{\mathrm{cd}}$ & $1.21^{\mathrm{a}}$ \\
\hline \multicolumn{7}{|c|}{ Average of Supplementation } \\
\hline & So & $72^{b}$ & $0.21^{\mathrm{b}}$ & $1.64^{\mathrm{b}}$ & 0.70 & $0.79^{\mathrm{b}}$ \\
\hline & $\mathrm{S} 1$ & $84^{\mathrm{a}}$ & $0.27^{\mathrm{a}}$ & $1.96^{\mathrm{a}}$ & 0.73 & $1.07^{\mathrm{a}}$ \\
\hline \multicolumn{7}{|c|}{ Average of Concentrate } \\
\hline & K0 & $57^{\mathrm{c}}$ & $0.14^{\mathrm{c}}$ & $1.66^{\mathrm{d}}$ & $0.63^{\mathrm{b}}$ & $0.82^{\mathrm{c}}$ \\
\hline & $\mathrm{K} 1$ & $73^{b}$ & $0.22^{\mathrm{b}}$ & $1.74^{\mathrm{c}}$ & $0.72^{\mathrm{a}}$ & $0.86^{\mathrm{c}}$ \\
\hline & $\mathrm{K} 2$ & $90^{\mathrm{a}}$ & $0.30^{\mathrm{a}}$ & $1.85^{\mathrm{b}}$ & $0.74^{\mathrm{a}}$ & $0.98^{b}$ \\
\hline & K3 & $92^{\mathrm{a}}$ & $0.31^{\mathrm{a}}$ & $1.96^{\mathrm{a}}$ & $0.77^{\mathrm{a}}$ & $1.06^{\mathrm{a}}$ \\
\hline
\end{tabular}

Source : Widiyanto et al. (2010)

a,b,c,d,e,f : Different superscripts in the same column indicate significantly different $(\mathrm{P}<0.05)$

DBWG: Daily Body Weigh Gain; TG: Triglyceride; LDL: Low Dencity Lipoprotein; HDL: High Dencity Lipoprotein 
Table 4. Intramuscular Fat Content, Cholesterol and Iodine Number, Linoleic Acid Relative Proportion in muskulus longisimus thoracis of Sheep

\begin{tabular}{|c|c|c|c|c|}
\hline Suplementation & Concentrate & $\begin{array}{c}\mathrm{IMF}^{1} \\
(\%)\end{array}$ & $\begin{array}{c}\text { Cholesterol }^{2} \\
(\mathrm{mg} / 100 \mathrm{~g})\end{array}$ & $\begin{array}{c}\text { Linoleic Acid }^{3} \\
(\%)\end{array}$ \\
\hline \multirow[t]{4}{*}{ So } & K0 & $3.04^{\mathrm{f}}$ & $74.95^{\mathrm{c}}$ & $2.53^{\mathrm{f}}$ \\
\hline & $\mathrm{K} 1$ & $3.75^{\mathrm{e}}$ & $86.11^{b}$ & $2.89^{\mathrm{f}}$ \\
\hline & $\mathrm{K} 2$ & $4.32^{\mathrm{d}}$ & $89.21^{\mathrm{a}}$ & $3.68^{\mathrm{e}}$ \\
\hline & K3 & $5.40^{\mathrm{b}}$ & $72.63^{\mathrm{c}}$ & $4.04^{\mathrm{e}}$ \\
\hline \multirow[t]{4}{*}{ S1 } & K0 & $3.45^{\mathrm{ef}}$ & $67.63^{\mathrm{d}}$ & $8.92^{\mathrm{d}}$ \\
\hline & K1 & $3.51^{\mathrm{e}}$ & $73.47^{\mathrm{c}}$ & $10.33^{\mathrm{c}}$ \\
\hline & $\mathrm{K} 2$ & $4.75^{\mathrm{c}}$ & $62.46^{\mathrm{e}}$ & $15.52^{\mathrm{b}}$ \\
\hline & $\mathrm{K} 3$ & $5.93^{\mathrm{a}}$ & $65.26^{\mathrm{de}}$ & $18.25^{\mathrm{a}}$ \\
\hline \multicolumn{5}{|c|}{ Average of Supplementation } \\
\hline & So & $4.12^{b}$ & $80.72^{\mathrm{a}}$ & $3.28^{\mathrm{b}}$ \\
\hline & S1 & $4.41^{\mathrm{a}}$ & $67.20^{\mathrm{b}}$ & $3.25^{\mathrm{a}}$ \\
\hline \multicolumn{5}{|c|}{ Average of Concentrate } \\
\hline & K0 & $3.24^{\mathrm{d}}$ & $71.29^{\mathrm{c}}$ & $5.73^{\mathrm{d}}$ \\
\hline & K1 & $3.63^{\mathrm{c}}$ & $79.79^{\mathrm{a}}$ & $6,61^{\mathrm{c}}$ \\
\hline & $\mathrm{K} 2$ & $4.53^{b}$ & $75.84^{b}$ & $9.60^{\mathrm{b}}$ \\
\hline & $\mathrm{K} 3$ & $5.66^{\mathrm{a}}$ & $68.94^{\mathrm{d}}$ & $11.14^{\mathrm{a}}$ \\
\hline
\end{tabular}

a,b,c,d,e,f,g : Different superscripts at the same column indicate the significantly different $(\mathrm{P}<0.05)$

$1:$ percent from fresh meat weight

2 : mg cholesterol per $100 \mathrm{~g}$ fresh meat

3 : percent of linoleic acid from total fatty acid of meat

IMF: Intramuscular Fat

of sheep in S0K3 group than S0K0, S0K1 and SOK2 (Table 3) were also supported by the increasing of androgen hormone secretion which also be synthesized from cholesterol (Murray, 1997). Enhancing of the use of cholesterol to fulfill the above requirement, it needed the taking of the extrahepatic tissue cholesterol, among other adipose tissue (Bell, 1979). Those phenomena maybe cause the lower $(\mathrm{P}<0.05)$ meat cholesterol content in SOK3 group than those in SOK1 and $\mathrm{S} 0 \mathrm{~K} 2$, and were not different from SOK0.

The intestinal cholesterol synthesis was expected increase due to protected $\mathrm{KSO}$ supplementation in $\mathrm{S} 1 \mathrm{~K} 0$ treatment group, as result of increasing the lipid consumption, namely $48.54 \mathrm{~g}$ (Table 2.). The increasing of cholesterol synthesis was accompanied by increasing of HDL synthesis (Table 3 ) which supported by increasing of linoleic acid supply. Those lipoprotein then took the cholesterol for esterification with linoleic acid, and took apart of low density (LDL) cholesterol, and then transported it to the liver through the enterohepatic pathway for oxydized became bile acid, to support the lipid digestion 
and absorption (Murray, 1997). The CE from unsaturated fatty acids was oxydized faster than those from saturated fatty acids. Unsaturated fatty acid stimulated cholesterol excretion through the intestine (Lough et al., 1992). The ration fed to sheep in S1K0 treatment group was forage only, namely field grass (FG), so that the undigested fiber bounded bile acids and increased its excretion in feces (Lough et al., 1992; Murray, 1997). Process on blood cholesterol which was synthesized through intestinal cholesterogenesis, thus did not increase the cholesterol deposition in adipose tissue, so that meat cholesterol content in S1K0 were lower $(\mathrm{P}<0.05)$ than those in S0K0 treatment group, although the lipid consumption in S1K0 was higher than S0K0.

Daily average of lipid consumption increased along with the increasing of RB feeding level in KSO supplemented sheep, that was 73.71; 87.95 and $98.87 \mathrm{~g}$, each in S1K1, S1K2 and S1K3 treatment groups (Table 2). The increasing of lipid consumption will be followed by increasing of bile acid secretion for digestion and absorption. The increasing of RB feeding level to sheep received KSO supplement, also resulted in increasing of body weight. Those physiological and biochemical process which resulted in increasing of body weight were supported by secretion of several substances, among other steroid hormone. Those cholesterol were taken by HDL from intestinal synthesis, other lipoprotein, particularly LDL and extrahepatic tissue (especially adipose tissue). It resulted in decreasing of meat cholesterol content along with increasing of RB feeding level in sheep received protected KSO supplemen (73.47, 62.46 and $65.26 \mathrm{mg} / 100 \mathrm{~g}$, each in S1K1, S1K2, and S1K3 treatment groups). The taking of cholesterol increased with increasing of HDL as result of the increasing of PUFA intake, which reflected in enhancing of HDL cholesterol content (Table 3).

\section{Linoleic Acid and Unsaturation Degree of Intramuscular Fatty Acid}

Relative proportion of meat linoleic acid of sheep received $15 \%$ without KSO supplementation (SOK1) was not significantly different from S0K0 treatment group, being 2.89 and $2.53 \%$, respectively (Table 4 .). Field grass as conventional feed was low in lipid content, approximately $1.37 \%$ only, so that lipid consumption in SoKo treatment group was also low, namely $6.04 \mathrm{~g} / \mathrm{head} /$ day. Main fatty acids constituent in forage lipid were linoleic acid and linolenic acid (Christie, 1979b; Byers and Schelling, 1988). Apart of those unsaturated fatty acids were avoided from rumen microbial biohydrogenation, absorbed from intestine and esterified as phospholipid and cholesteryl ester (Bell, 1979; Petit et al., 2002; Jenkins and Bridges, 2007). Those esterification was conservation mechanism of unsaturated fatty acids because its metabolism became slow (French et al., 2000). The RB, had higher lipid content than forage $(17.08 \%)$. Those cereal lipid was linoleic fatty acid source (Christie, 1979b).

Feeding RB at $15 \%$ level increased the lipid consumption from 6.04 up to $16.66 \mathrm{~g} /$ day. Biohydrogenation process in the rumen resulted in not significantly different linoleic acid deposition from sheep received FG only. Increasing of RB proportion (up to $45 \%$ level) to the sheep without KSO supplementation resulted in increasing of linoleic acid relative proportion significantly $(\mathrm{P}<$ 0.05 ), that was $3.68 \%$ in $\mathrm{S} 0 \mathrm{~K} 2$ and $4.04 \%$ in SOK3. Readily available carbohydrate source (RB) could decrease the rumen fluid $\mathrm{pH}$, so that inhibited liopolytic microbes to hydrolize the ester bound between fatty acid and glycerol, so that avoided the formation of fatty acid with free carboxyl group (Bauman et al., 2003). The presence of carboxyl group was prerequisite of biohydrogenation process of double bound in PUFA (Araujo et al., 2010). Thus, the increasing of RB proportion in S0K2 and S0K3 treatment group could increase the bypassed PUFA from ruminal biohydrogenation, so that increased its deposition in meat.

Table 4 indicated that the increasing of linoleic acid relative proportion in $m$. longisimus thoracis was followed by the increasing of unsaturation degree of intramuscular fatty acids. Those was reflected in increasing of iodin number (IN) along with the increasing of RB level(3.07; 3.66; 4.09 and 4.98 in S0K0, S0K1, S0K2, S0K3, respectively). In addition to increasing of linoleic acid relative proportion, the increasing of unsaturation degree of intramuscular fatty acids also due to the decreasing of palmitic and stearic acids relative proportion. It was in accordance with Christie opinion (1979a), who stated that compensatoir decreasing of palmiitic and stearic acid could occur along with increasing of linoleic acid relative proportion. Decreasing of palmitic and stearic acids occured because inhibition of de novo fatty acid synthesis of both fatty acids as result of increasing of linoleic acid taking by adipose tissue (Vernon, 1979). The PUFA could 
inhibite gen transcription for fatty acid synthetase enzyme, especially acetyl-CoAcarboxylase, so that resulted in de novo fatty acids biosynthesis inhibition (Clarke, 1993; French et al., 2000; Wood et al., 2008).

Protected KSO supplementation to sheep without feeding RB resulted in linoleic acid relative proportion $8.92 \%$ with 6.96 IN (Table 4.). Those were higher than meat linoleic acid relative proportion and unsaturation degree of intramuscular fat in sheep without KSO supplementation, although fed RB up to $45 \%$ level (proportion of linoleic acid was $8.92 \%$ with 6.96 IN). It caused by protected KSO supplementation which allowed higher lipid consumption (48.54 vs $45.21 \mathrm{~g}$ ) and higher post ruminal linoleic acid supply than sheep groups without KSO supplementation. The increasing of linoleic acid supply which available for absorption resulted in higher meat linoleic relative proportion and IN in S1 K0 than in S0K3 group.

Combination treatment between $15 \%$ level of feeding $\mathrm{RB}$ and protected KSO supplementation (S1K1) resulted in $10.33 \%$ linoleic acid proportion. Those were higher $(\mathrm{P}<0.05)$ than linoleic acid proportion in S1K0 group (8.92\%). Christie (1979b) explained that if the available PUFA in intestine exceeded tha capacity of esterification to phospholipid and cholesteryl ester, a significant number of PUFA will be esterified as TG component and non esterified fatty acids (NEFA), and then was taken by adipose tissue. As energy source, PUFA will be oxydized faster than saturated fatty acids. It will decrease its deposition in adipose tissue (Peng et al., 2010). Microbial fermentation of RAC (in this case was RB) in the rumen resulted in VFAs with high proportion of propionic acid (Hungate, 1966). Throughout gluconeogenesis process in liver, most of propionic acid was converted to glucose. Those in adipose tissue will increase the acetic acid as energy source, so that it will decrease the PUFA oxydation. Those increased the oportunity of PUFA from TG and non esterified PUFA for deposited in adipose tissue (Christie, 1979a; Gibb et al., 2005). The above fenomenon was expected caused the higher of linoleic acid relative proportion in combination between KSO supplementation and RB than KSO supplementation without RB sheep groups.

Furthermore the increasing of linoleic acid proportion (15.52 and $18.25 \%$ ) was found in sheep supplemented by protected KSO with feeding 30 and $45 \%$ level of RB, respectively. In addition to above factors, increasing of linoleic acid relative proportion could be caused by increasing of lipid consumption and PUFA which available in post ruminal digestive tract, due to increasing of RB portion level.

Without KSO supplementation, increasing of feeding RB from $30 \%$ to $45 \%$ did not result in significant difference of meat linoleic acid relative proportion. Significantly increase occured through combination with KSO supplementation, namely $15.52 \%$ in $\mathrm{S} 1 \mathrm{~K} 2$ to $18.25 \%$ in S1K3. The lower relative proportion of meat linoleic acid was found in S1K2 than S1K3, in addition to lower lipid consumption, also expected due to higher of conversion rate of linoleic acid became to arachidonic acid (Smith et al., 2009). Sardesai (1992) stated that arachidonic acid was main product of desaturation and elongation from linoleic acid. Amount of those elongation and desaturation appeared from the higher of IN ( $\mathrm{P} \leq$ $0.05)$ in S1K2 treatment group than S1K2 (12.52 vs 10.25). The increasing of conversion of linoleic acid to arachidonic acid was required to support the increasing of physiological and biological activity, which reflected in the better performance of sheep in S1K2 than in S1 K3 treatment group, especially in body weight gain (Table 3 .).

\section{CONCLUSIONS}

Supplementation of protected KSO decreased meat cholesterol content. Protected KSO supplementation which combined with RAC source concentrate (in this case was RB), increased the proportion of omega 6 fatty acid (linoleic acid) and unsaturation degree of meat fatty acid.

\section{ACKNOWLEDGMENTS}

Authors thank to "Direktorat Pembinaan Penelitian dan Pengabdian kepada Masyarakat, Direktorat Jenderal Pendidikan Tinggi, Kementerian Pendidikan Nasional Republik Indonesia" for funding this research (contract number : 319/SP3/PP/DP2M/II/2006).

\section{REFERENCES}

Aharoni, Y., A. Orlov, and A. Brosh. 2004. Effects of high-forage content and oilseed supplementation of fattening diets on conjugated linoleic acid (CLA) and trans fatty acids profiles of beef lipid fractions. J. 
Anim. Sci. And Techno. 117:43-60.

Araujo, D.B., R.F. Cooke, G.R. Hansen, C.R. Staples and J.D. Arthington. 2010. Effects of rumen-protected polyunsaturated fatty acid supplementation on performance and physiological responses of growing cattle after transportation and feedlot entry. J. Anim. Sci. 88 (12):4120-4132

Arinto. 2006. Produksi dan pemasaran dalam pembangunan peternakan di Indonesia. In: Utomo, R., S.P.S. Budhi, Sumadi, T. Haryadi, C.T. Noviandi. (eds..). Menyongsong Rencana Kecukupan Daging Tahun 2010. (Prosiding Orasi dan Seminar Pelepasan Dosen Purna Tugas 2006). Fakultas Peternakan UGM. Yogyakarta. Pp.202-232.

Bauman, D.E., J.W. Perfield 1l, M.J. de Veth, and A.L. Lock. 2003. New perspectives on lipid digestion and metabolism in ruminants. Proc. Cornell Nutr. Conf. pp.175-189.

Bell, A.W. 1979. Lipid metabolism in liver and selected tissues and in the whole body of ruminant animals. In : W.W. Christie. (ed.). Lipid Metabolism in Ruminant Animals. Pergamon Press. New York. pp. 363 - 403.

Bergen, W.G. and H.J. Mersmann. 2005. Comparative aspects of lipid metabolism : impact on contemporary research and use of animal models. J. Nutr. 135 (11) : 2499-2502

Bonnet, M., Y. Faulconnier, C. Leroux, C. Jurie, L.C. Malek, D. Bauchart, P. Boulesteix, D. Pethick, J.F. Hocquette, and J. Chilliard. 2007. Glucose-6-phosphate dehydrogenase and leptin are related to marbling differences among Limousin and Angus or Japanese Black Angus x Angus steers. J. Anim. Sci. 85 (11) : 2882-2894

Byers, F.M. and G.T. Schelling. 1988. Lipid in ruminant nutrition. In : D.C. Church. (ed.). The Ruminant Animal Digestive Physiology and Nutrition. A Reston Book, Prentice Hall, Englewood Cliffs, New Jersey. pp. 298 324.

Borys, B., A. Borys, and R. Gasior. 2004. Effect of feeding rapeseed and linseed diets and their supplementation with vitamin $\mathrm{E}$ on health quality of lamb meat. Arch. Tierz., Dummerstorf 47. Special Issue, 189-197

Chen, X.J., H.L. Mao, X.M. Ma, and J.X. Liu. 2010. Effects of dietary corn oil and vitamin E supplementation on fatty acid profiles and expression of acetyl CoA carboxylase and stearoyl-CoA desaturase gene in $\mathrm{Hu}$ sheep.
Anim. Sci. J. 81 : 165-171

Chilliard, Y., F. Glasser, A. Ferlay, R.M. Mansbridge, and M. Doreau. 2007. Diet, Rumen Biohydrogenation and nutritional quality of cow and goat milk fat. European J. Lipid Sci. Tech. 109 (8) : 828-855

Christie, W.W. 1979a. The composition, structure and function of lipids in the tissues of ruminant animals. In : W.W. Christie (ed.).Lipid Metabolism in Ruminant Animals. Pergamon Press. New York.pp. 95 $-190$.

Christie, W.W. 1979b. The effect of diet and other factors on the lipid composition of ruminant tissues and milk. In : W.W. Christie. (ed.). Lipid Metabolism in Ruminant Animals. Pergamon Press. New York. pp. 193-220.

Clarke, S.D. 1993. Regulation of fatty acid synthetase gene expression : an approach for reducing fat accumulation. J. Anim. Sci. 71: 1957-1965.

Ditjen Bina Produksi Peternakan. 2006. Hasil Pertemuan Koordinasi Teknis Lingkup Direktorat Jenderal Bina Produksi Peternakan Wilayah Timur. Makasar,5-7 June 2006.

Dodson, M.V., G.J. Hausman, L.L. Guan, M. Du, T.P. Rasmussen, S.P. Poulos, P. Mir, W.G. Bergen, M.E. Fernyhough, D.C. McFarland, R.P. Rhoads, B.Soret, J.M. Reecy, S.G. Velleman, and Z. Jiang. 2010. Lipid metabolism, adipocyte depot physiology and utilization of meat animals as experimental models for metabolic research. Int. J. Biol. Sci. 6 (7) : 691-699

Doreau, M., D. Bauchart and Y. Chilliard. 2010. Enhancing fatty acid composition of milk and meat through animal feeding. Anim. Prod. Sci. 51 (1) : 19-29

Faulconnier, J., I.O. Marty, C. Delavaud, D. Dozias, R. Jailler, D. Micol, and Y. Chilliard. 2007. Influence of the diet and grazing on adipose tissue lipogenic activities and plasma leptin in steers. Animal (9):12631271

French, D., C. Stanton, F. Lawless, G.C. O. Riordan, F.J. Monahan, P.J. Caffrei, and A.P. Moloney. 2000. Fatty acid composition, including conjugated linoleic acid, of intramuscular fat from steers offered grazed grass, grass silage, or concentrate - based diets. J. Anim. Sci. $78: 2849-2855$.

Gibb, D.J., M.A. Shah, P.S. Mir, and T.A. McAllister. 2005. Effect of full-fat hemp 
seed on performance and tissue fatty acids of feedlot cattle. Can. J. Anim. Sci. 85 : 223230

Harris, L.E. 1970. Nutrition Research Techniques for Domestic and Wild Animals. Vol. I. Anim. Sci. Dept. Utah State Univ. Logan. Utah.

Hess, B.W., G.E. Moss and D.C. Rule. 2008. A decade of developments in the area of fat supplementation research with beef cattle and sheep. J. Anim. Sci. 86 (E-suppl.): E188E204

Hungate, R.E. 1966. The Rumen and Its Microbes. Academic Press. New York and london.

Jalc, D., M. Certik, K. Kundrikova and P. Namestkova. 2007. Effect of unsaturated $\mathrm{C}_{18}$ fatty acids (oleic, linoleic And $\alpha$-linolenic acid) on ruminal fermentation and production of fatty acid isomers in an artificial rumen. Veterinarni Medicina. 52(3):87-94

Jenkins, T.C., and W.C. Bridges Jr. 2007. Protection of fatty acids against ruminal biohydrogenation in cattle. European J. Lipid Sci. Tech. 109 (8):778-789

Laliotis, G.P., L. Bizelis and E. Rogdakis. 2010. Comparative approach of the denovo fatty acid synthesis (lipogenesis) between ruminant and non ruminant mammalian species : from biochemical level to the main regulatory lipogenic genes. Curr Genomics. 11 (3) : 168-183

Lough, D.S., M.B. Salomon, T.S. Rumsey, T.H. Elsster, L.L. Slyter, S. Kahl and G.P. Lynch.1992. Effect dietary canola seed and soy lecithin in high-forage diets on cholesterol content and fatty acid composition of carcass tissue of growing lamb. J. Anim. Sci. 70:1153-1158.

Murray, R.K., D.K. Granner, P.A. Mayes, and V.W. Rodwell. 1997. Harper's Biochemistry. $24^{\text {th }}$ Ed. Published by Appleton \& Lange.

Nuernberg, K., K. Ender and D. Dannenberger. 2006. Possibilities to produce healthy, tasty meat and to improve its nutritional value. Pol. J. Food Nutr. Sci. 15/56 (1):17-21

Peng, Y.S., M.A. Brown, J.P. Wu and Z. Liu. 2010. Different oilseed supplements alter fatty acid composition of different adipose tissues of adult ewes. Meat Sci. 85:542-549

Pethick, D.W., D.N. D'Sousa, F.R. Dunshea and G.S. Harper. 2005. Fat metabolism and regional distributyion in ruminant and pigs- influences of genetics and nutrition. Recent Advance in Animal Nutrition in Australia. 15 : 39-45

Petit, H.V., G.F. Tremblay, E. Tremblay and P. Nadeau. 2002. Ruminal biohydrogenation of fatty acids, protein degradability, and dry matter degradability treated with different sugar and heat combinations. Canadian J. Anim. Sci. 82 (2) : 241-150

Plumer, D.T. 1971. An Introduction to Practical Biochemistry. Tata McGraw-Hill Co. Ltd. Bombay.

Ponnampalam, E.N., A.J. Sinclair, A.R. Egan, S.J. Blakeley, D. Li and B.J. Leury. 2001. Effect of dietary modification of muscle long chain n-3 fatty acid on plasma insulin and lipid metabolites, carcass traits, and fat deposition in lambs. J. Anim. Sci. 78:895-903.

Raes, K., S.D. Smet and D. Demeyer. 2004. Effect of dietary fatty acids on incorpotration of long chain polyunsaturated fatty acids and conjugated linoleic acid in lamb, beef and pork meat. Anim. Feed Sci. Tech. 113 (1-4) : 199-221

Sardesai, V.M. 1992. Nutritional role of polyunsaturated fatty acids. J. Nutr. Biochem. $3: 154$ - 162 .

Scolland, N.D., M. Enser, S.K. Gulati, L. Richardson and J.D. Wood. 2003. Effect of including a ruminally protected lipid supplement in the diet on the fatty acid composition of beef muscle. British J. Nutr. $90: 709-716$

Sheridan, R., L.C. Hoffman and A.V. Ferreira. 2003. Meat quality of Boer goat kids and Mutton Merino lambs 1. Commercial yields and chemical composition. Anim. Sci. 76 : 63-71

Smith, S.B., C.A. Gill, D.K. Lunt and M.A. Brooks. 2009. Regulation of fat and fatty acid composition in beef cattle. Asian-Aust. J. Anim. Sci. 22 (9) : 1225-1233

Sugandi, E. and Sugiarto. 1993. Rancangan Percobaan. Andi Offset. Yogyakarta.

Tillman, A.D. 1978. Ilmu Nutrisi Ruminansia. Fakultas Peternakan Universitas Gadjah Mada, Yogyakarta.

Tranggono, B. Setiaji, Suhardi, Sudarmanto, Y. Marsono, A. Murdiati, I.S. Utami and Suparmo. 1989. Biokimia Pangan. PAU Pangan - Gizi UGM. Yogyakarta.

Vakili, A., A. Mortezaee and M.D. Mesgaran. 2011. The effect of glucogenic and lipogenic diets on blood metabolites of Baloochi 
sheep. World Academy Science, Engineering and Technology. 59 : 946-948

Vernon, R.G. 1979. Lipid metabolism in the adipose tissue of ruminant animals. In : W.W. Christie. (ed.). Lipid Metabolism in Ruminant Animals. Pergamon Press. New York. pp. $279-353$.

Widiyanto, M. Soejono, Z. Bachrudin, H. Hartadi and Surahmanto. 2007. Pengaruh suplementasi minyak biji kapok terproteksi terhadap daya guna pakan serat secara in vitro. J. Pengembangan Peternakan tropis. 32 (1) : 51-57.

Widiyanto, M. Soejono, Z. Bachrudin, H. Hartadi and Surahmanto. 2009. Suplementasi minyak biji kapok terproteksi untuk meningkatkan produktivitas domba lokal jawa ekor kurus. Prosiding Seminar Nasional : Pengembangan Ternak Potong untuk Mewujudkan Program Kecukupan Swasembada Daging. Fakultas Peternakan Universitas Gadjah Mada, Yogyakarta, 7 November 2009. Hal. : 138 - 154.

Widiyanto, M. Soejono, Z. Bachrudin, H. Hartadi and Surahmanto. 2010. Blood lipid status of "Jawa Ekor Kurus" sheep supplemented by protected kapok seed oil. Proceedings, Part II. The $8^{\text {th }}$ International Seminar on Tropical Animal Production, Faculty of Animal Science, Universitas Gadjah Mada, Yogyakarta, Indonesia, October 19-22, 2010. P. $497-501$.

Wood, J.D., R.I. Richardson, G.R. Nute, A.V. Fisher, M.M. Campo, E. Kasapidou, P.R. Sheard and M. Enser. 2004. Effects of faty acids on meat quality : a review. Meat Sci. $66(1): 21-32$

Wood, J.D., M. Enser, A.V. Fisher, G.R. Nute, P.R. Sheard, R.I. Richardson, S.I. Hughes and F.M. Whitington. 2008. Fat deposition, fatty acid composition and meat quality. Meat Sci. 78:343-358

Zhang, X.D., W.J. Chen, C.Y. Li, and J.X. Liu. 2009. Effects of proteoin-free energy supplementation on blood metabolites, insulin and hepatic PEPCK gene expression in growing lambs offered rice straw-based diet. Czech J. Anim. Sci. 54(11):481-489 